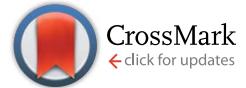

Cite this: RSC Adv., 2017, 7, 17545

Received 1st March 2017 Accepted 17th March 2017

DOI: $10.1039 / \mathrm{c} 7 \mathrm{ra02528a}$

rsc.li/rsc-advances

\title{
Hybrid flavan-flavanones from Friesodielsia desmoides and their inhibitory activities against nitric oxide production $\uparrow$
}

\author{
Pornphimol Meesakul, ${ }^{a}$ Khanitha Pudhom, ${ }^{\text {b }}$ Stephen G. Pyne \\ and Surat Laphookhieo*a
}

\begin{abstract}
The first phytochemical investigation of Friesodielsia desmoides leaves and twigs led to the isolation and identification of three new hybrid flavan-flavanones, friesodielsones A-C (1-3), together with 18 known compounds (4-21). The structures of compounds 1-3 were elucidated through intensive analysis of spectroscopic data and their absolute configurations at C-2 and C-4 were determined by a combination of ${ }^{1} \mathrm{H}$ NMR and CD spectroscopy. The configuration at C-2" is tentatively assigned as $2^{\prime \prime} \mathrm{S}$ based on biosynthesis considerations. Compounds 2 and 15 significantly inhibited NO production with $\mathrm{IC}_{50}$ values of $10.21 \pm 0.074$ and $7.56 \pm 0.087 \mu \mathrm{M}$, respectively, whereas compounds $11\left(\mathrm{IC}_{50}=28.14 \pm 0.024 \mu \mathrm{M}\right)$ and $12\left(\mathrm{IC}_{50}=37.21 \pm 0.017 \mu \mathrm{M}\right)$ were moderate inhibitors.
\end{abstract}

\section{Introduction}

Friesodielsia is a small genus belonging to the Annonaceae family which is distributed in Africa and Asia. Five species, including $F$. desmoides, F. fornicata, F. discolor, $F$. filipes, and $F$. kingii, are found in Thailand. ${ }^{1}$ Many types of secondary metabolites are produced from this genus including flavonoids, ${ }^{1,2}$ chalcones, ${ }^{1,3}$ alkaloids, ${ }^{3}$ benzyl benzoate derivatives ${ }^{2}$ and sesquiterpenes. ${ }^{2}$ Some of these compounds show interesting biological properties, such as antiplasmodial ${ }^{1,3}$ and cytotoxicity activities. ${ }^{\mathbf{1} 3}$ F. desmoides (Craib) Steenis (Fig. 1) is a small tree or shrub that is grown as an ornamental plant in Thailand. This plant has two synonymous names, Goniothalamus desmoides Craib and Oxymitra desmoides. To the best of our

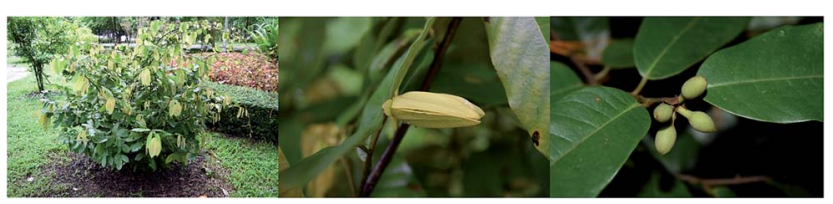

Fig. 1 Friesodielsia desmoides (these photos were taken by Surat Laphookhieo).

\footnotetext{
${ }^{a}$ Natural Products Research Laboratory, School of Science, Mae Fah Luang University, Chiang Rai, 57100, Thailand.E-mail: surat.lap@mfu.ac.th

${ }^{b}$ Department of Chemistry, Faculty of Science, Chulalongkorn University, Bangkok, 10330 Thailand

${ }^{c}$ School of Chemistry, University of Wollongong, Wollongong, New South Wales, 2522 Australia
}

$\dagger$ Electronic supplementary information (ESI) available. See DOI: 10.1039/c7ra02528a knowledge, this is the first report of phytochemical investigations of this plant. Three new hybrid flavan-flavanones (1-3) along with 18 known compounds (4-21) (Fig. 2) were isolated and identified from $F$. desmoides leaves and twigs that were collected from Mae Fah Luang University Health Park, Chiang Rai Province, Thailand. Most of the isolated compounds were evaluated for their NO inhibitory activities.

\section{Results and discussion}

The crude extracts of $F$. desmoides leaves and twigs were separated by column chromatography using various stationary phases to yield three new hybrid flavan-flavanones, friesodielsones A-C (1-3), along with 18 known compounds (4-21). The known compounds were identified as desmosflavan A (4), ${ }^{4}$ desmosflavan B (5), ${ }^{4}$ (2S)-8-formyl-5,7-dihydroxyflavanone (6), ${ }^{\mathbf{1}}$ alpinetin (7), ${ }^{5}$ pinocembrin (8), ${ }^{5}$ 5,6,7-trihydroxy-flavanone (9), ${ }^{6}$ 5,6-dihydroxy-7-methoxy-flavanone $(\mathbf{1 0}),{ }^{7}$ cardamonin (11), ${ }^{5}$ $2^{\prime}, 4^{\prime}$-dihydroxy-3', $6^{\prime}$-dimethoxychalcone $\quad(\mathbf{1 2}){ }^{8} \quad$ trans-dihy- $^{8}$ droquercetin (13), ${ }^{9}$ quercetin $(\mathbf{1 4}),{ }^{10}$ chrysin $(\mathbf{1 5}),{ }^{11} O$-methylmoschatoline (16), ${ }^{12} \quad$ (-)-epicatechin (17), ${ }^{13} \quad 3^{\prime}$-formyl-2', $4^{\prime}$ dihydroxy- $6^{\prime}$-methoxychalcone (18), ${ }^{1} \mathrm{O}$-aristololactam BII (19), ${ }^{14}$ aristololactam AIa (20) ${ }^{\mathbf{1 4}}$ and goniothalamin (21). ${ }^{\mathbf{1 5}}$

Friesodielsone A (1) was obtained as a yellow solid. It showed a pseudomolecular ion peak at $m / z[\mathrm{M}-\mathrm{H}]^{-} 523.1393$ (calcd 523.1393) in the HRESIMS corresponding to a molecular formula of $\mathrm{C}_{31} \mathrm{H}_{24} \mathrm{O}_{8}$. The ${ }^{1} \mathrm{H},{ }^{13} \mathrm{C}$, DEPT and 2D NMR spectroscopic data of $\mathbf{1}$ (Table 1) suggested this compound contained two moieties, a flavan unit and a flavanone unit. ${ }^{16}$ The flavan unit displayed ${ }^{1} \mathrm{H}$ and ${ }^{13} \mathrm{C}$ NMR signals for a hydrogen-bonded hydroxyl proton $\left[\delta_{\mathrm{H}} 12.35(1 \mathrm{H}, \mathrm{s}, 7-\mathrm{OH})\right]$, a formyl group $\left[\delta_{\mathrm{H}}\right.$ $\left.10.10(1 \mathrm{H}, \mathrm{s}, 8-\mathrm{CHO}) / \delta_{\mathrm{C}} 192.1\right]$, a monosubstituted aromatic ring 


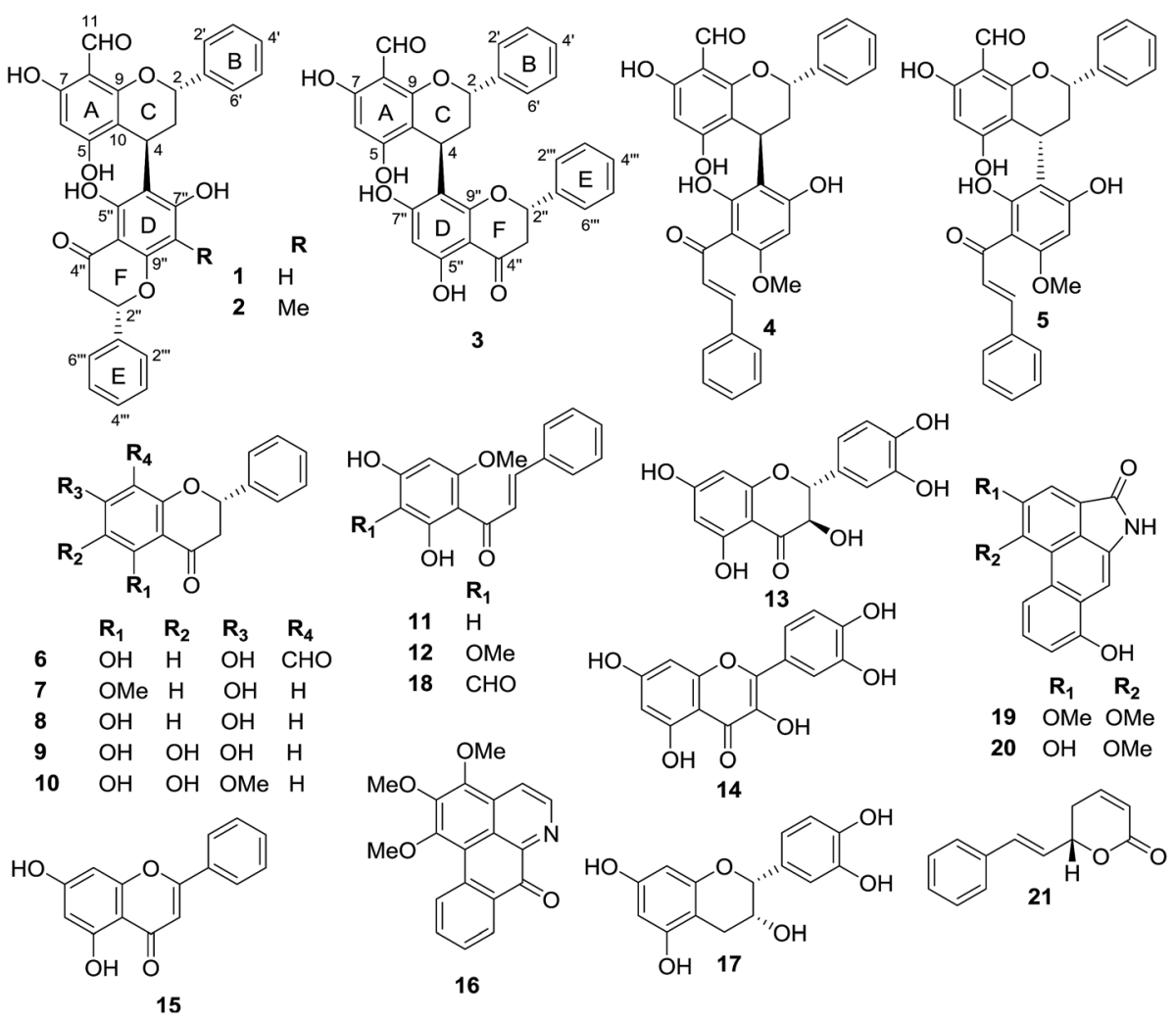

Fig. 2 Compounds isolated from F. desmoides leaves and twigs.

$\left[\delta_{\mathrm{H}} 7.44-7.47\left(2 \mathrm{H}, \mathrm{m}, \mathrm{H}-2^{\prime}, \mathrm{H}-6^{\prime}\right) / \delta_{\mathrm{C}} 126.8,7.40-7.42(2 \mathrm{H}, \mathrm{m}, \mathrm{H}-\right.$ $\left.3^{\prime}, \mathrm{H}-5^{\prime}\right) / \delta_{\mathrm{C}} 129.4$, and $\left.7.30-7.34\left(1 \mathrm{H}, \mathrm{m}, \mathrm{H}-4^{\prime}\right) / \delta_{\mathrm{C}} 128.6\right]$, an isolated aromatic proton $\left[\delta_{\mathrm{H}} 5.90(1 \mathrm{H}, \mathrm{s}, \mathrm{H}-6) / \delta_{\mathrm{C}} 94.9\right]$, and an $\mathrm{AB}_{2} \mathrm{C}$ proton spin system (deduced from COSY spectrum) $\left[\delta_{\mathrm{H}}\right.$ $5.53(1 \mathrm{H}, \mathrm{dd}, J=3.5,10.0, \mathrm{H}-2) / \delta_{\mathrm{C}} 76.7,2.24-2.33(2 \mathrm{H}, \mathrm{m}, \mathrm{H}-3) /$ $\delta_{\mathrm{C}} 37.9$, and $\left.4.67(1 \mathrm{H}, \mathrm{dd}, J=2.6,5.4 \mathrm{~Hz}, \mathrm{H}-4) / \delta_{\mathrm{C}} 26.1\right]$. The formyl group was located at C-8 $\left(\delta_{\mathrm{C}} 105.9\right)$ from the HMBC correlations (Fig. 3) of C-8 $\left(\delta_{\mathrm{C}} 105.9\right)$ to the hydrogen-bonded hydroxyl proton $\left(\delta_{\mathrm{H}}\right.$ 12.35), the formyl proton $\left(\delta_{\mathrm{H}} 10.10\right)$ and the isolated aromatic proton $\mathrm{H}-6\left(\delta_{\mathrm{H}} 5.90\right)$.

The second fragment, a flavanone unit, showed ${ }^{1} \mathrm{H}$ and ${ }^{13} \mathrm{C}$ NMR resonances for a hydrogen-bonded hydroxyl $\left[\begin{array}{ll}\delta_{\mathrm{H}} & 12.73\end{array}\right.$ $\left.\left(1 \mathrm{H}, \mathrm{s}, 5^{\prime \prime}-\mathrm{OH}\right)\right]$, a monosubstituted aromatic ring $\left[\delta_{\mathrm{H}} 7.56-7.58\right.$ $\left(2 \mathrm{H}, \mathrm{m}, \mathrm{H}-2^{\prime \prime \prime}, \mathrm{H}-6^{\prime \prime \prime}\right) / \delta_{\mathrm{C}} 127.8,7.43-7.47\left(2 \mathrm{H}, \mathrm{m}, \mathrm{H}-3^{\prime \prime \prime}, \mathrm{H}-5^{\prime \prime \prime}\right) / \delta_{\mathrm{C}}$ 129.5 , and $\left.7.40-7.43\left(1 \mathrm{H}, \mathrm{m}, \mathrm{H}-4^{\prime \prime \prime}\right) / \delta_{\mathrm{C}} 129.4\right]$, an isolated aromatic proton $\left[\delta_{\mathrm{H}} 6.08\left(1 \mathrm{H}, \mathrm{s}, \mathrm{H}-8^{\prime \prime}\right) / \delta_{\mathrm{C}} 95.9\right]$ and an $\mathrm{AB}_{2}$ proton spin system (deduced from COSY spectrum) $\left[\delta_{\mathrm{H}} 5.57(1 \mathrm{H}, \mathrm{dd}, J=\right.$ $\left.3.0,13.5 \mathrm{~Hz}, \mathrm{H}-2^{\prime \prime}\right) / \delta_{\mathrm{C}} 79.9,2.80\left(1 \mathrm{H}, \mathrm{dd}, J=3.0,17.1 \mathrm{~Hz}, \mathrm{H}-3^{\prime \prime}\right) / \delta_{\mathrm{C}}$ 43.7 and $3.16\left(1 \mathrm{H}\right.$, dd, $\left.\left.J=13.5,17.1 \mathrm{~Hz}, \mathrm{H}-3^{\prime \prime}\right) / \delta_{\mathrm{C}} 43.7\right]$.

The flavan and flavanone units of $\mathbf{1}$ had a $\mathrm{C}-\mathrm{C}$ bond linkage between C-4 of ring $\mathrm{C}$ and C-6" ${ }^{\prime \prime}$ of ring $\mathrm{D}$ which was deduced from the following HMBC correlations: $\delta_{\mathrm{H}} 4.67(\mathrm{H}-4)$ with $\mathrm{C}-5^{\prime \prime}$ $\left(\delta_{\mathrm{C}} 163.1\right), \mathrm{C}-6^{\prime \prime}\left(\delta_{\mathrm{C}} 111.9\right)$ and $\mathrm{C}-7^{\prime \prime}\left(\delta_{\mathrm{C}} 165.2\right)$; and $\delta_{\mathrm{H}} 2.24-2.33$ $(\mathrm{H}-3)$ with $\mathrm{C}-6^{\prime \prime}\left(\delta_{\mathrm{C}}\right.$ 111.9). The assignments of the NMR spectroscopic data of $\mathbf{1}$ are summarized in Table 1 . Therefore, friesodielsone A was identified as structure 1 . The relative configuration of the C-ring of $\mathbf{1}$ was deduced to be the same as that of desmosflavan A (4), ${ }^{4}$ from the similarity of their ${ }^{1} \mathrm{H}$ NMR coupling constants for the protons $\mathrm{H}-2, \mathrm{H}-3$ and $\mathrm{H}-4$. The absolute $4 S$ configuration of $\mathbf{1}$ was evident from the positive Cotton effect (Fig. 4) at $\lambda_{\max }(\Delta \varepsilon) 225.5\left(2.92 \times 10^{4}\right) \mathrm{nm} .{ }^{17-19}$ This allowed the assignment of the $2 S$ configuration of 1 based on the aforementioned ${ }^{1} \mathrm{H}$ NMR comparisons. The configuration at $\mathrm{C}-2^{\prime \prime}$ could not be unequivocally determined but is based on the biosynthetic consideration outline in Scheme 1.

Friesodielsone B (2) was obtained as a yellow solid. Its molecular formula, $\mathrm{C}_{32} \mathrm{H}_{26} \mathrm{O}_{8}$, was obtained from HRESIMS analysis which showed a $[\mathrm{M}-\mathrm{H}]^{-}$at $m / z 537.1549$ (calcd for $\left.\mathrm{C}_{32} \mathrm{H}_{25} \mathrm{O}_{8}, 537.1549\right)$. The ${ }^{1} \mathrm{H}$ and ${ }^{13} \mathrm{C}$ NMR spectroscopic data of 2 (Table 1) were similar to those of $\mathbf{1}$. The main differences were the ring $\mathrm{D}$ resonances of the flavanone unit. Compound 2 displayed an additional resonance for methyl protons at $\delta_{\mathrm{H}} 2.09(3 \mathrm{H}$, s) and the absence of the $\mathrm{C}-8^{\prime \prime}$ aromatic proton resonance at $\delta_{\mathrm{H}}$ $6.08\left(1 \mathrm{H}, \mathrm{s}, \mathrm{H}-8^{\prime \prime}\right)$ as was observed in 1 . The HMBC correlation (Fig. 3) between these methyl protons $\left(\delta_{\mathrm{H}} 2.09\right)$ and $\mathrm{C}-8^{\prime \prime}\left(\delta_{\mathrm{C}}\right.$ 159.1) further supported the position of this methyl group at $\mathrm{C}-8$. The assignments of the ${ }^{1} \mathrm{H}$ and ${ }^{13} \mathrm{C}$ spectroscopic data of 2 are summarized in Table 1 . The CD spectrum of 2 (Fig. 4) and ${ }^{1} \mathrm{H}$ NMR coupling constants of $\mathrm{H}-2, \mathrm{H}-3$ and $\mathrm{H}-4$ were similar to that of 1 indicating that the absolute configuration at C-2 and C-4 of 2 and 1 were the same. This was further supported by their similar and negative specific optical rotations, $[\alpha]_{\mathrm{D}}^{25}-57.6(c 0.03, \mathrm{MeOH})$ for 1 and $[\alpha]_{\mathrm{D}}^{26}-45.1$ (c $\left.0.006, \mathrm{MeOH}\right)$ for 2. Thus, friesodielsone B was assigned the structure 2 .

Friesodielsone C (3) was obtained as a yellow solid. Its HRESIMS spectrum showed a $[\mathrm{M}-\mathrm{H}]^{-}$at $m / z 523.1393$ (calcd 
Table $1{ }^{1} \mathrm{H}(400 \mathrm{MHz})$ and ${ }^{13} \mathrm{C}(100 \mathrm{MHz})$ spectroscopic data for friesodielsones $\mathrm{A}-\mathrm{C}$

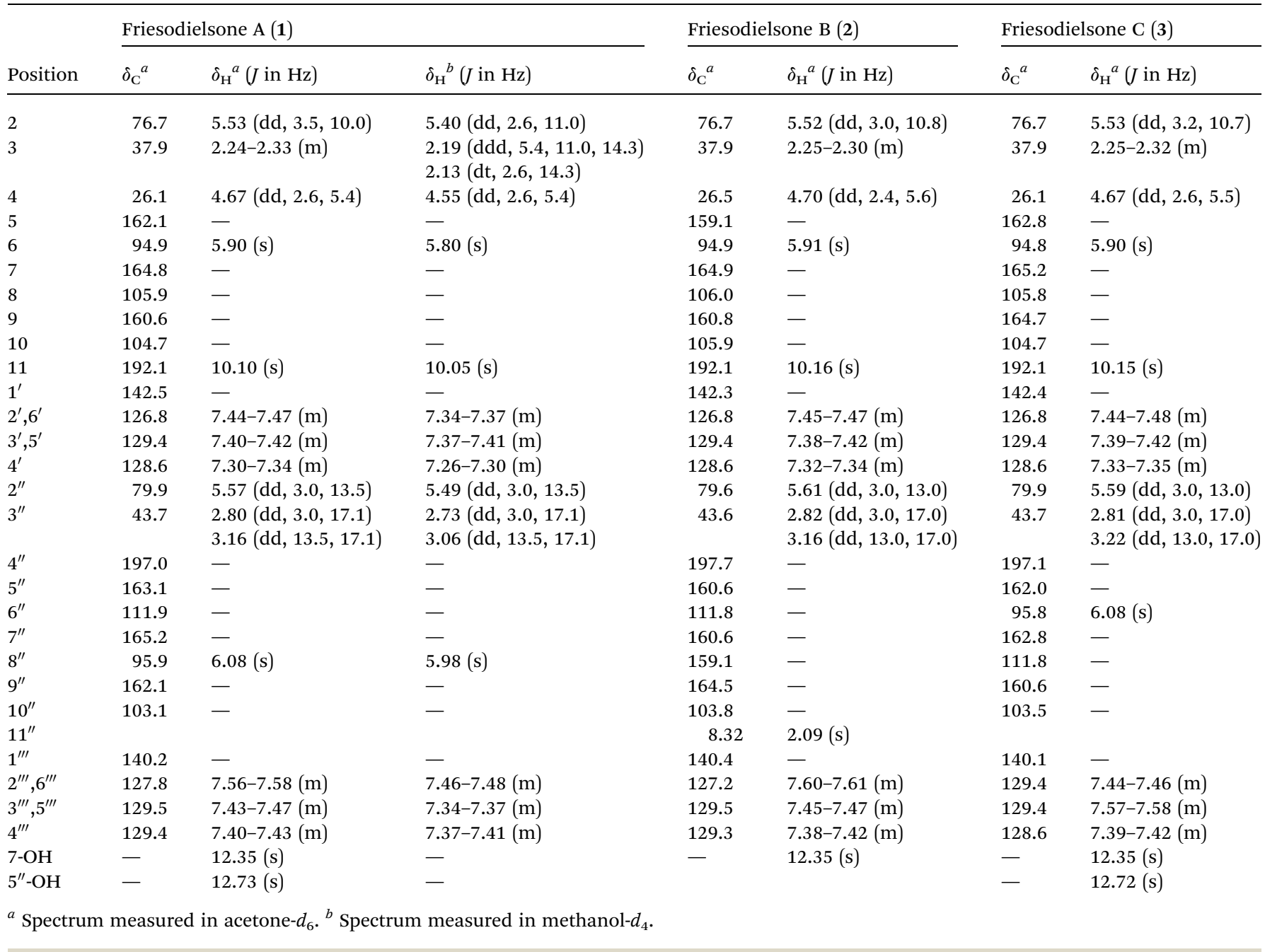
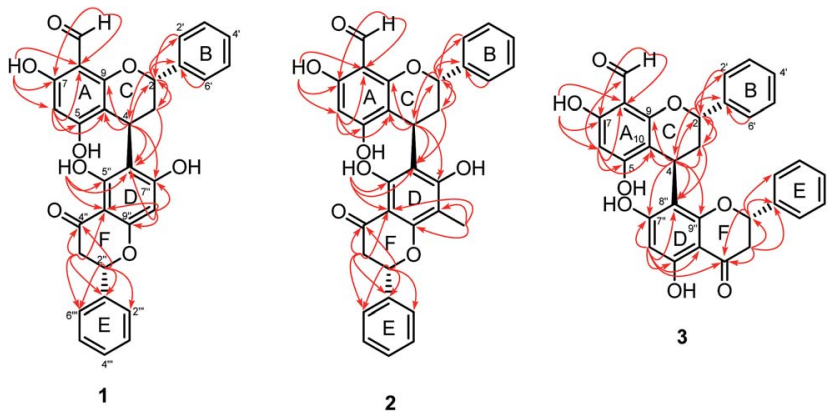

Fig. 3 Selected HMBC correlations of compounds 1-3.

523.1393) corresponding to the molecular formula of $\mathrm{C}_{31} \mathrm{H}_{24} \mathrm{O}_{8}$. The ${ }^{1} \mathrm{H}$ and ${ }^{13} \mathrm{C}$ NMR spectroscopic data of 3 (Table 1) were similar to those of $\mathbf{1}$ and 2 . The significant difference in the structure of $\mathbf{3}$ was the position of flavan-flavanone linkage. Compounds 1 and 2 were linked at C-4/C- 6 " whereas compound 3 was linked at C-4/C-8". The HMBC correlations of $\delta_{\mathrm{H}} 4.67(\mathrm{H}-4)$ to $\mathrm{C}-7^{\prime \prime}\left(\delta_{\mathrm{C}} 162.0\right), \mathrm{C}-8^{\prime \prime}\left(\delta_{\mathrm{C}} 111.8\right)$ and $\mathrm{C}-9^{\prime \prime}\left(\delta_{\mathrm{C}} 162.8\right)$ supported this $\mathrm{C}-4 / \mathrm{C}-8^{\prime \prime}$ linkage (Fig. 3). The absolute configuration at C-4

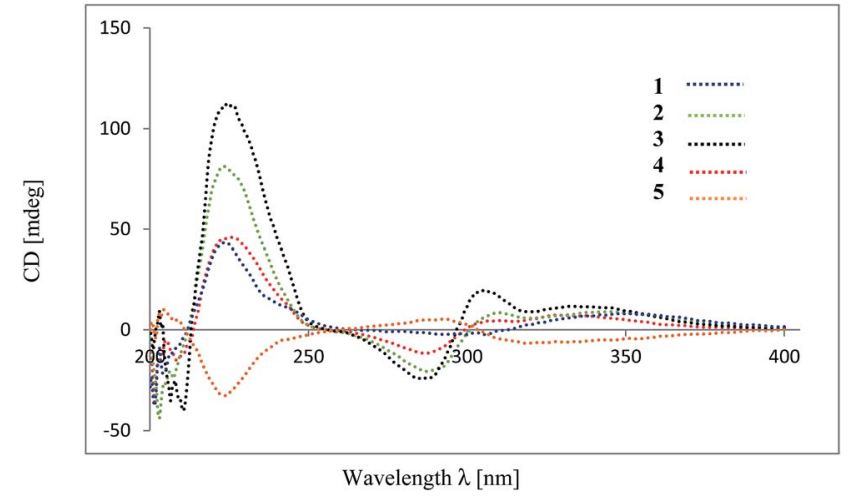

Fig. $4 \mathrm{CD}$ spectra $(\mathrm{MeOH})$ of compounds 1-5.

of 3 was determined by comparison of its CD spectrum with that of compounds 1 and 2. The absolute configuration at C-4 of 3 was the same as that of $\mathbf{1}$ and $\mathbf{2}$ from the positive Cotton effect seen in its CD spectrum (Fig. 4) at $\lambda 224 \mathrm{~nm}$, which was similar to those of compounds 1 and 2. Therefore, friesodielsone $\mathrm{C}$ was assigned the structure 3 . 


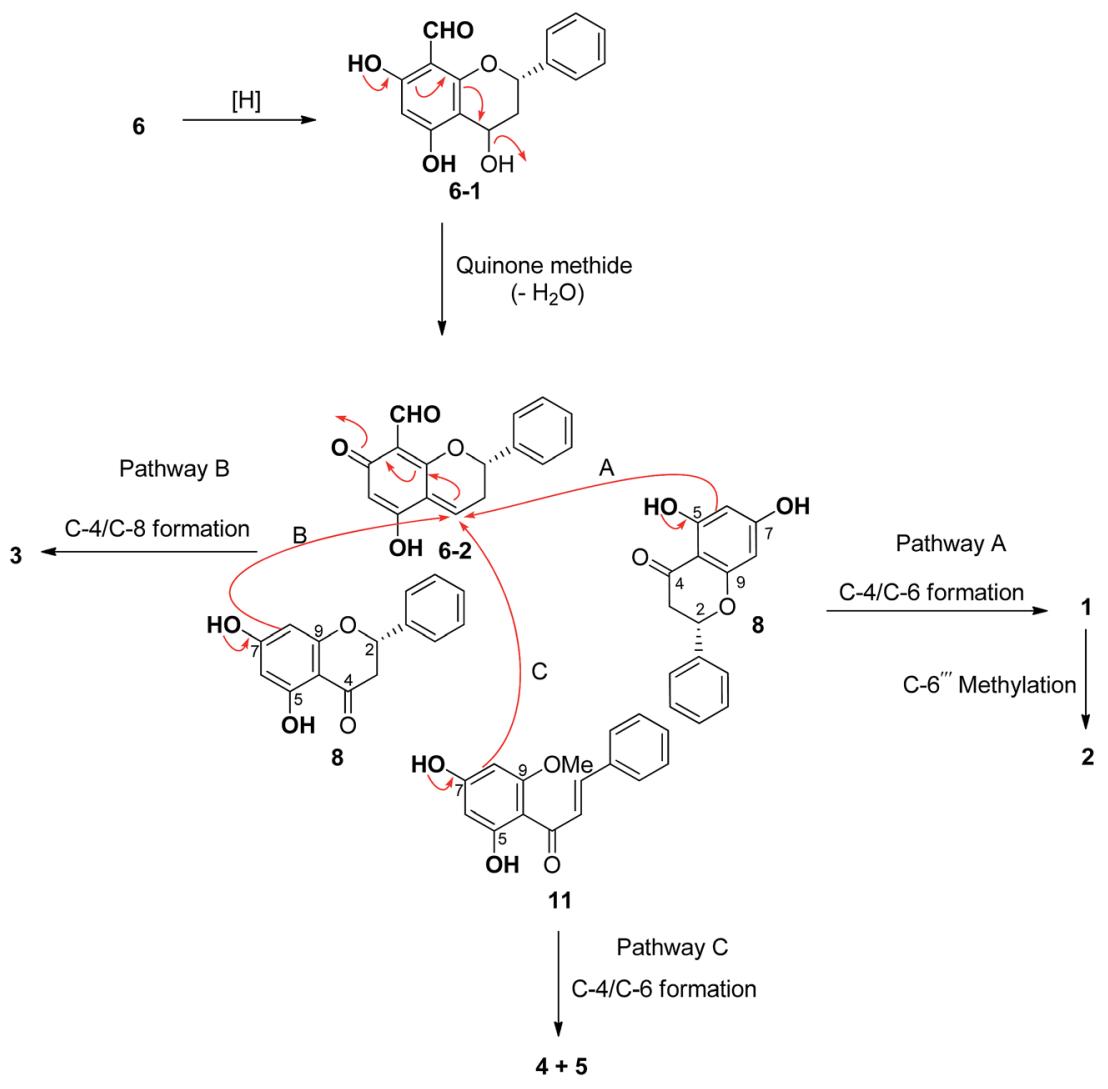

Scheme 1 Plausible biosynthetic pathway of compounds $1-5$.

Hybrid biflavonoids comprising a linked flavan and flavanone units are rarely found as natural products. ${ }^{16,20-23}$ Biosynthetically, compounds 1-3 could be derived from compound 6 (Scheme 1) via reduction of the C-4 carbonyl group and then formation of the para-quinone methide 6-2 by dehydration. ${ }^{24}$ Intermediate 6-2 could couple with compound 8 at C-4/C-6 to provide compound 3 (via pathway B) and at C-4/C-6 to produce

Table 2 NO production inhibition effect and cytotoxicity on J774.A1 cells

\begin{tabular}{lll}
\hline Compounds & $\begin{array}{l}\text { NO production } \\
\mathrm{IC}_{50}, \mu \mathrm{M}\end{array}$ & $\begin{array}{l}\text { MTT\% cell } \\
\text { viability at } 10 \mu \mathrm{M}\end{array}$ \\
\hline $\mathbf{1}$ & Inactive & 116.2 \\
$\mathbf{2}$ & $10.21 \pm 0.074$ & 126.6 \\
$\mathbf{5}$ & Inactive & 102.5 \\
$\mathbf{6}$ & Inactive & 72.80 \\
$\mathbf{7}$ & Inactive & 73.00 \\
$\mathbf{8}$ & Inactive & 90.90 \\
$\mathbf{9}$ & Inactive & 97.40 \\
$\mathbf{1 0}$ & Inactive & 78.10 \\
$\mathbf{1 1}$ & $28.14 \pm 0.024$ & 98.30 \\
$\mathbf{1 2}$ & $37.21 \pm 0.017$ & 97.80 \\
$\mathbf{1 3}$ & Inactive & 82.20 \\
$\mathbf{1 5}$ & $7.56 \pm 0.087$ & 84.30 \\
$\mathbf{1 6}$ & Inactive & 76.60 \\
$\mathbf{1 7}$ & Inactive & 82.90 \\
$\mathbf{2 1}$ & Inactive & 64.40 \\
Indomethacin & $28.4 \pm 3.5$ & -
\end{tabular}

compounds 1 and 2 (via pathway A). The latter compound obtained from 1 via methylation at C-6"' $6^{\prime \prime}$. Similarly, the biosynthetic pathway to compounds $\mathbf{4}$ and $\mathbf{5}$ could be derived from the coupling of compounds 6-2 and $\mathbf{1 1}$ (Scheme 1). The isolation of compounds $\mathbf{6 , 8}$ and $\mathbf{1 1}$ in this study supports this biosynthetic hypothesis. The absolute configuration tentatively assigned as $2^{\prime \prime} S$ at C-2" in compounds 1-3 is based on this biosynthetic hypothesis.

Most of the isolated compounds were evaluated for their NO inhibitory activities in J774.A1 macrophage cells. Compounds 2 and 15 significantly exhibited NO production with $\mathrm{IC}_{50}$ values of $10.21 \pm 0.074$ and $7.56 \pm 0.087 \mu \mathrm{M}$, respectively, whereas compounds $11\left(\mathrm{IC}_{50}=28.14 \pm 0.024 \mu \mathrm{M}\right)$ and $12\left(\mathrm{IC}_{50}=37.21 \pm\right.$ $0.017 \mu \mathrm{M}$ ) were more moderate inhibitors (Table 2). Significantly, the active compounds, 2, 11, 12 and 15, did not show cytotoxicity at $10 \mu \mathrm{M}$ against J774.A1 cells (Table 2).

\section{Conclusion}

Friesodielsia is a small genus in the Annonaceae family. To the best of our knowledge, only three species have been investigated phytochemically and the major compounds are flavonoids. ${ }^{1-3}$ However, a few chalcones, ${ }^{1,3}$ alkaloids, ${ }^{3}$ benzyl benzoate derivatives $^{2}$ and sesquiterpenes ${ }^{2}$ were also been found. In this study, 21 compounds were isolated and identified including three new unique hybrid flavan-flavones (1-3), two hybrid flavanchalcones (4 and 5), nine flavonoids $(6-10,13-15,17)$, three 
chalcones $(\mathbf{1 1 - 1 2}, \mathbf{1 8})$, three alkaloids and one styryl lactone (21). A hypothesis for the biosynthesis of compounds 1-5 from a para-quinone methide intermediate derived from compound 6 is proposed. This is the first reported isolation of compounds 4-10, 13-17, and 19-21 from this genus. Compounds 2, 11, 12 and 15 inhibited NO production indicating that they might be potential lead compounds for further study and development as anti-inflammatory agents.

\section{Experimental}

\section{General experimental procedures}

Melting points were determined on a Stuart SMP3 Melting Point Apparatus. The $[\alpha]_{\mathrm{D}}$ values were measured with a Bellingham and Stanley ADP400 polarimeter. UV-vis spectra were recorded with a BMG LABTECH/SPECTROstar Nano spectrometer. The circular dichroism (CD) spectra were measured on a JASCO J-815 apparatus. The IR spectra were recorded using a PerkinElmer FTS FT-IR spectrometer. The NMR spectra were recorded using a $400 \mathrm{MHz}$ Bruker AM 400 spectrometer in acetone- $d_{6}$ with TMS as an internal standard. The HRESIMS were obtained on a Bruker microTOF mass spectrometer. Silica gel $\mathrm{C}_{60}(0-20$ $\mu \mathrm{m}$, SiliCycle ${ }^{\circledR}$ Inc.) and silica gel G60 (60-200 $\mu \mathrm{m}$, SiliCycle® Inc.) were used to perform quick column chromatography (QCC) and column chromatography (CC), respectively. Analytical thin-layer chromatography (TLC) was performed with the precoated plates of silica gel $60 \mathrm{~F}_{254}$. The macrophage J774.A1 cells were purchased from CLS (Cell Line Service, Germany).

\section{Plant material}

The twigs and leaves of $F$. desmoides were collected in August 2015 from an authentically identified plant growing at Mae Fah Luang University Health Park, Chiang Rai Province, Thailand. The plant specimen (no. MFU-NPR0102) was deposited at the Natural Products Research Laboratory, School of Science, Mae Fah Luang University.

\section{Extraction and isolation}

Air-dried leaves of $F$. desmoides (564.3 g) were extracted with EtOAc $(5 \mathrm{~L})$ over a period of 3 days at room temperature. Removal of the solvent provided the crude EtOAc extract (49.42 $\mathrm{g})$, which was subjected to QCC over silica gel, eluting with a gradient of hexanes-EtOAc (100\% hexanes to $100 \%$ EtOAc) to give compound $\mathbf{6}(5.2 \mathrm{mg}), \mathbf{1 4}(6.5 \mathrm{mg})$ and nine fractions (A-I). Fractions C $(1.59 \mathrm{~g})$ was further separated by CC $(100 \% \mathrm{DCM})$ to give compounds $\mathbf{9}(17.1 \mathrm{mg})$ and $\mathbf{1 0}(6.3 \mathrm{mg})$. Fraction $\mathrm{D}(2.38 \mathrm{~g})$ was subjected to CC using reverse phase silica gel $(4: 1 \mathrm{MeOH} /$ $\mathrm{H}_{2} \mathrm{O}$ ) to afford four subfractions (DA-DD). Compound 7 (14.7 $\mathrm{mg}$ ) was obtained from subfraction DA $(31.4 \mathrm{mg})$ by Sephadex LH-20 (100\% MeOH). Subfraction DC (173.4 mg) was further separated by CC (100\% DCM) to yield compounds 11 (13.6 mg) and $12(14.2 \mathrm{mg})$. Fraction $\mathrm{F}(1.30 \mathrm{~g})$ was subjected to CC using reverse phase silica gel $\left(4: 1 \mathrm{MeOH} / \mathrm{H}_{2} \mathrm{O}\right)$ to afford three subfractions (FA-FC). Purification of subfraction FC $(526.9 \mathrm{mg})$ by CC (1: 4 acetone/hexanes) gave compounds $1(16.8 \mathrm{mg})$ and 3 (5.3 mg). Fraction G (1.09 g) was further separated by CC using reverse phase silica gel $\left(4: 1 \mathrm{MeOH} / \mathrm{H}_{2} \mathrm{O}\right)$ to obtained seven subfractions (GA-GG). Subfractions GC $(376.5 \mathrm{mg})$ was further purified by CC (100\% DCM), yielding compounds $2(7.0 \mathrm{mg}), 4$ $(3.1 \mathrm{mg})$ and $5(4.5 \mathrm{mg})$. Compounds $6(7.4 \mathrm{mg})$ and $\mathbf{1 4}(5.5 \mathrm{mg})$ were obtained from fraction $\mathrm{H}(1.21 \mathrm{~g})$ by repeated CC $(3: 7$ acetone/hexanes). Fraction I (1.84 g) was further separated by CC using reverse phase silica gel $\left(4: 1 \mathrm{MeOH} / \mathrm{H}_{2} \mathrm{O}\right)$ to obtained four subfractions (IA-ID). Subfraction IC $(451.8 \mathrm{mg})$ was further purified by CC ( $2: 3$ acetone/hexanes) to afford compounds $\mathbf{1 3}$ (12.4 mg) and 16 (4.3 mg).

Air-dried twigs of $F$. desmoides $(1.26 \mathrm{~kg})$ were extracted with EtOAc $(5 \mathrm{~L})$ over a period of 3 days at room temperature. Removal of the solvent provided the crude EtOAc extract (52.02 $\mathrm{g}$ ), which was subjected to QCC over silica gel, eluting with a gradient of hexanes-EtOAc (100\% hexanes to $100 \%$ EtOAc) to give five fractions (A-E). Fraction B (396.1 mg) was separated on Sephadex LH-20 $(100 \% \mathrm{MeOH})$ to obtained four subfractions (BA-BD). Subfractions BC (165.9 mg) was further purified by CC (100\% DCM), yielding compound 21 (2.8 mg). Compounds 11 (10.1 mg) and $15(1.4 \mathrm{mg})$ were obtained from subfraction BD (93.7 mg) by CC (100\% DCM). Purification of fraction C (745.9 $\mathrm{mg}$ ) by CC (1:4 acetone/hexanes) yielded compounds 17 (6.8 $\mathrm{mg})$ and $18(6.0 \mathrm{mg})$. Fractions $\mathrm{D}(325.0 \mathrm{mg})$ was further purified by CC $(1: 9 \mathrm{EtOAc} / \mathrm{DCM})$ to give compound $16(5.3 \mathrm{mg})$. Compounds $19(1.3 \mathrm{mg})$ and $20(1.4 \mathrm{mg})$ were obtained from fraction $\mathrm{E}(212.5 \mathrm{mg})$ by CC $(0.5: 9.5 \mathrm{MeOH} / \mathrm{DCM})$.

Friesodielsone A (1). Yellow powder; mp 244-246 ${ }^{\circ} \mathrm{C}$; $[\alpha]_{\mathrm{D}}^{25}-57.6$ ( c 0.03, MeOH); UV (MeOH) $\lambda_{\max }(\log \varepsilon) 245$ (3.51), $313(3.40) \mathrm{nm}$; CD $(\mathrm{MeOH}) \lambda_{\max }(\Delta \varepsilon) 328\left(4.72 \times 10^{3}\right), 311(2.99$ $\left.\times 10^{3}\right), 286\left(-7.41 \times 10^{3}\right)$ and $225.5\left(2.92 \times 10^{4}\right) \mathrm{nm}$; IR (neat) $\nu_{\max } 3087,2924,2851,1652,1614,1580,1501,1449,1167,766$ $\mathrm{cm}^{-1}$; see Table 1 for ${ }^{1} \mathrm{H}$ NMR (acetone- $d_{6}, 400 \mathrm{MHz}$ ) and ${ }^{13} \mathrm{C}$ NMR (acetone- $d_{6}, 100 \mathrm{MHz}$ ); HRESIMS $m / z 523.1393[\mathrm{M}-\mathrm{H}]^{-}$ (calcd for $\mathrm{C}_{31} \mathrm{H}_{23} \mathrm{O}_{8}$, 523.1393).

Friesodielsone B (2). Yellow powder: $\mathrm{mp}$ 167-169 ${ }^{\circ} \mathrm{C}$; $[\alpha]_{\mathrm{D}}^{26}-45.1$ ( $c$ 0.006, MeOH); UV (MeOH) $\lambda_{\max }(\log \varepsilon) 235$ (3.61), 298 (3.64), 340 (3.33) nm; CD (MeOH) $\lambda_{\max }(\Delta \varepsilon) 322\left(3.52 \times 10^{4}\right)$, $311\left(4.92 \times 10^{4}\right), 289\left(-1.19 \times 10^{5}\right)$, and $225\left(4.70 \times 10^{5}\right) \mathrm{nm}$; IR (neat) $\nu_{\max } 3434,2920,2851,1634,1441,1373,1275,1111,618$ $\mathrm{cm}^{-1}$; see Table 1 for ${ }^{1} \mathrm{H}$ NMR (acetone- $d_{6}, 400 \mathrm{MHz}$ ) and ${ }^{13} \mathrm{C}$ NMR (acetone- $d_{6}, 100 \mathrm{MHz}$ ); HRESIMS $m / z$ 537.1549 [M - H] $]^{-}$ (calcd for $\mathrm{C}_{32} \mathrm{H}_{25} \mathrm{O}_{8}, 537.1549$ ).

Friesodielsone C (3). Yellow powder: $\mathrm{mp} 178-181{ }^{\circ} \mathrm{C}$; $[\alpha]_{\mathrm{D}}^{25}-63.2(c 0.03, \mathrm{MeOH}) ; \mathrm{UV}(\mathrm{MeOH}) \lambda_{\max }(\log \varepsilon) 240(4.27)$, 298 (4.33), 340 (3.75) nm; CD (MeOH) $\lambda_{\max }(\Delta \varepsilon) 344\left(7.00 \times 10^{3}\right)$, $305\left(1.24 \times 10^{4}\right), 286\left(-1.56 \times 10^{4}\right)$, and $224\left(7.15 \times 10^{4}\right)$; IR (neat) $\nu_{\max } 3200,2928,2854,1634,1443,1371,1275,1161,1167$, $766 \mathrm{~cm}^{-1}$; see Table 1 for ${ }^{1} \mathrm{H}$ NMR (acetone- $d_{6}, 400 \mathrm{MHz}$ ) and ${ }^{13} \mathrm{C}$ NMR (acetone- $d_{6}, 100 \mathrm{MHz}$ ); HRESIMS $m / z$ 523.1393 [M $\mathrm{H}]^{-}$(calcd for $\mathrm{C}_{31} \mathrm{H}_{23} \mathrm{O}_{8}$, 523.1393).

\section{Nitric oxide production inhibitory assay}

The effects of the isolated compounds on nitric oxide production in murine macrophage J774.A1 cells (Cell Line Service, Germany) in supernatant were determined using the previously reported method. ${ }^{22}$ In brief, J774.A1 cells were 
added in 96-well plate with $5 \times 10^{5}$ cells per well and incubated for $1 \mathrm{~h}$ at $37{ }^{\circ} \mathrm{C}$ and $5 \% \mathrm{CO}_{2}$. After that, cells were treated with various concentrations of sample or vehicle (DMSO) for $2 \mathrm{~h}$, followed by LPS $10 \mu \mathrm{g} \mathrm{mL}^{-1}$. After $18 \mathrm{~h}$ incubation, NO production in the culture medium was determined using the Griess reagent (1\% sulfanilamide in $5 \%$ phosphoric acid and $0.1 \%$ naphthylethylenediamine dihydrochloride in distilled water) for $10 \mathrm{~min}$ and the absorbance was measured at $540 \mathrm{~nm}$. Indomethacin was used as a positive control.

\section{Cell viability assay}

The measurement of cell viability of the tested compounds was performed using the 3-[4,5-dimethylthiazol-2-yl-2,5diphenyltetrazolium] bromide (MTT) assay against unstimulated J774.A1 cells. ${ }^{25}$ Briefly, $10 \mu \mathrm{L}$ of fresh MTT solution ( $5 \mathrm{mg} \mathrm{mL} \mathrm{m}^{-1}$ in saline) was added to each well, incubated at $37^{\circ} \mathrm{C}$ in $\mathrm{CO}_{2}$ for $3 \mathrm{~h}$. The media was discarded and DMSO was added to dissolve the formazan crystals and the absorbance value at $540 \mathrm{~nm}$ was measured. The percentages of cell survival were calculated from the absorbance value of the tested compounds and control (LPS) using the equation below.

$$
\% \text { cell viability }=\frac{\mathrm{Abs}_{\text {sample }}}{\mathrm{Abs}_{\mathrm{LPS}}} \times 100
$$

\section{Acknowledgements}

This research was financially supported by the Thailand Research Fund and Mae Fah Luang University through the Basic Research Grant (BRG5980012), the Thailand Research Fund through the Royal Golden Jubilee PhD Program (PHD/0010/ 2558) and Direct Basic Research Grant (DBG5980001) and the Mae Fah Luang University Graduate Student Research Grant. S. L. thanks the Australian Government via the Endeavour Award 2016 for a research fellowship. Mae Fah Luang University and the University of Wollongong are also acknowledged for laboratory facilities.

\section{Notes and references}

1 U. Prawat, D. Phupornprasert, A. Butsuri, A.-W. Salae, S. Boonsri and P. Tuntiwachwuttikul, Phytochem. Lett., 2012, 5, 809-813.

2 T. C. Fleischer, R. D. Waigh and P. G. Waterman, Phytochemistry, 1997, 44, 315-318.
3 C. C. Joseph, J. J. Magadula and M. H. H. Nkunya, Nat. Prod. Res., 2007, 21, 1009-1015.

4 S. P. Bajgai, V. Prachyawarakorn, C. Mahidol, S. Ruchirawat and P. Kittakoop, Phytochemistry, 2011, 72, 2062-2067.

5 M. Kuroyanagi, T. Noro, S. Fukushima, R. Aiyama, A. Ikuta, H. Itokawa and M. Morita, Chem. Pharm. Bull., 1983, 31, 1544-1550.

6 N. Narasimhachari, V. D. N. Sastri and T. R. Seshadri, Proc. Natl. Acad. Sci., India, Sect. A, 1949, 29, 404-412.

7 P. V. Kiem, C. V. Minh, H. T. Huong, J. J. Lee, I. S. Lee and Y. H. Kim, Arch. Pharmacal Res., 2005, 28, 1345-1349.

8 K. Ichino, H. Tanaka, K. Ito, T. Tanaka and M. Mizuno, J. Nat. Prod., 1988, 51, 906-914.

9 E. Kiehlmann and E. P. M. Li, J. Nat. Prod., 1995, 58, 450-455.

10 M. A. Aderogba, A. R. Ndhlala, K. R. Rengasamy and J. Van Staden, Molecules, 2013, 18, 12633-12644.

11 H. Shimura, M. Matsuura, N. Takada and Y. Koda, Phytochemistry, 2007, 68, 1442-1447.

12 K. Mahmood, K. C. Chan, M. H. Park, Y. N. Han and B. H. Han, Phytochemistry, 1986, 25, 1509-1510.

13 G. Wang, X. Huang, D. Pei, W. Duan, K. Quan, X. Li and D. Di, New J. Chem., 2016, 40, 3885-3891.

14 H. A. Priestap, Phytochemistry, 1985, 24, 849-852.

15 K. Jewers, J. B. Davis, J. Dougan, A. H. Manchanda, G. Blunden, A. Kyi and S. Wetchapinan, Phytochemistry, 1972, 11, 2025-2030.

16 C.-M. Cao, L.-J. Xu, Y. Peng, Q.-W. Shi and P.-G. Xiao, Chem. Pharm. Bull., 2010, 58, 1395-1398.

17 Y. Ding, X.-C. Li and D. Ferreira, J. Nat. Prod., 2010, 73, 435440.

18 M. S. Pesca, F. D. Piaz, R. Sanogo, A. Vassallo, M. B. de Abreu, A. Rapisarda, M. P. Germanó, G. Certo, S. D. Falco, N. De Tommasi and A. Braca, J. Nat. Prod., 2013, 76, 29-35.

19 J. Coetzee, J. P. Steynberg, P. J. Steynberg, E. V. Brandt and D. Ferreira, Tetrahedron, 1995, 51, 2339-2352.

20 A. J. Birch and C. J. Dahl, Aust. J. Chem., 1974, 27, 331-344.

21 A. J. Birch, C. J. Dahl and A. Pelter, Tetrahedron Lett., 1967, 481-487.

22 J. C. S. Malan, D. A. Young, J. A. Steenkamp and D. Ferreira, J. Chem. Soc., Perkin Trans. 1, 1988, 2567-2572.

23 J. Coetzee, J. P. Steynberg, J. P. Steynberg, V. E. Brandt and D. Ferreira, Tetrahedron, 1995, 51, 2339-2352.

24 M. R. Attwood, B. R. Brown, S. G. Lisseter, C. L. Torrero and P. M. Weaver, J. Chem. Soc., Chem. Commun., 1984, 177-179.

25 K. Pudhom and T. Teerawatananond, J. Nat. Prod., 2014, 77, 1962-1966. 